\begin{tabular}{|c|l|}
\hline Title & $\begin{array}{l}\text { Survival of Glochidial Larvae of the Freshwater Pearl Mussel, Margaritifera laevis (Bivalvia: Unionoida), at Different } \\
\text { Temperatures: A Comparison Between Two Populations With and Without Recruitment }\end{array}$ \\
\hline Author(s) & A kiyama, Y oshihiro; I Iwakuma, Toshio \\
\hline Citation & $\begin{array}{l}\text { Zoological Science, 24(9), 890-893 } \\
\text { https://doi.org/L0.2108/2si.24.890 }\end{array}$ \\
\hline Issue Date & 2007-09 \\
\hline Doc URL & http:/hdl.handle.net/2115/34756 \\
\hline Type & article \\
\hline File Information & akiyama.pdf () \\
\hline
\end{tabular}

Instructions for use 


\title{
Survival of Glochidial Larvae of the Freshwater Pearl Mussel, Margaritifera laevis (Bivalvia: Unionoida), at Different Temperatures: A Comparison Between Two Populations With and Without Recruitment
}

\author{
Yoshihiro Akiyama $^{1 *}$ and Toshio Iwakuma ${ }^{2}$ \\ ${ }^{1}$ Division of Bioscience, Graduate School of Environmental Earth Science, \\ Hokkaido University, Sapporo 060-0810, Japan \\ ${ }^{2}$ Section of Environmental Biology, Faculty of Environmental Earth \\ Science, Hokkaido University, Sapporo 060-0810, Japan
}

\begin{abstract}
The viability of free-living glochidia of the freshwater pearl mussel (Margaritifera laevis) was studied in the laboratory at water temperatures of $10^{\circ} \mathrm{C}, 15^{\circ} \mathrm{C}$ and $20^{\circ} \mathrm{C}$. To obtain glochidia, gravid female mussels were collected from the Chitose River, inhabited by adult and juvenile mussels, and from the Abira River, where only adult mussels were found. Daily survival rates of glochidia from each population at various water temperatures were significantly different, and survival time was longest at the lowest temperature in each population. Maintenance of some field mussel populations might become difficult at higher water temperatures due to the short survival time of glochidia and expected low density of host fish. Daily survival rates of glochidia were compared between the Abira population at $15^{\circ} \mathrm{C}$ and the Chitose population at $20^{\circ} \mathrm{C}$, since these temperatures were close to the mean water temperature during the period of glochidial release in the respective rivers. Daily mean survival rates were significantly different between the Abira population at $15^{\circ} \mathrm{C}$ and the Chitose population at $20^{\circ} \mathrm{C}$. Mean glochidial survival rate for the Chitose population changed from $85.3 \%$ to $66.2 \%$ from 9 to $13 \mathrm{~h}$, whereas that for the Abira population dropped suddenly from $80.4 \%$ to $34.2 \%$ from 10 to $14 \mathrm{~h}$ after the initiation of experiment. Absence of juveniles in the Abira River might have been caused by the low glochidial viability. Survival times of free-living glochidia in Margaritiferidae tend to be shorter than in other families in Unionoida. A trade-off is suggested between high fertility and low glochidial survival rate in Margaritiferidae.
\end{abstract}

Key words: glochidium, Margaritifera laevis, survival, temperature effect, population

\section{INTRODUCTION}

Unionoida (Bivalvia) all live in freshwater, and their larvae, known as glochidia, are ectoparasitic on the gills and/or fins of fish (Wachtler et al., 2001) and the gills of amphibians (Watters and Scott, 1998), except for Mycetopodidae and Mutelidae, whose larvae are called lasidia and/or haustoria, with a different life history from other Unionoida (Wachtler et al., 2001). Margaritifera laevis belongs to Unionoida and its maximum age reaches 79 years (Awakura, 1969). This species lives in cool water $\left(<23^{\circ} \mathrm{C}\right)$ (Yoshida, 1971). The glochidial larvae drift in water after being released from a gravid female mussel (Kobayashi and Kondo, 2005), infect gills of suitable hosts such as masu salmon (Oncorhynchus masou masou), red-spot masu trout (Oncorhynchus masou ishikawae), chum salmon (Oncorhynchus keta), sockeye salmon (Oncorhynchus nerka) and rainbow trout (Oncorhynchus mykiss) for about a month

\footnotetext{
* Corresponding author. Phone: +81-11-706-2245; Fax : +81-11-706-2245; E-mail: akiyama@ees.hokudai.ac.jp
}

doi:10.2108/zsj.24.890
(Awakura, 1964; Habe, 1982), and transform into free-living juveniles that drop and settle in sediment. Glochidia of $M$. laevis cannot parasitize the white-spotted char, Salvelinus leucomaenis, which serves as a host for a closely related mussel, Margaritifera togakushiensis (Kondo and Kobayashi, 2005).

Margaritifera laevis is listed in Endangered Species Category II by the Ministry of the Environment, Japan (Kondo, 2005). The major causes of its extinction are alterations of habitat (Kondo, 1995), such as damming that limits host-fish density (Awakura, 1969) and river improvement (Yoshida, 1973). The glochidial survival rate for M. margaritifera becomes lower with increasing rearing temperature (Jansen et al., 2001). A similar phenomenon probably occurs in $M$. laevis. Glochidia cannot survive without infecting host fishes, because they do not feed during the free-living glochidial stage (Jansen et al., 2001). Since the free-living glochidial stage is the most vulnerable in the life history (Bauer, 2001), the population dynamics of Margaritiferidae perhaps depend strongly on the survival rate at this stage. Therefore, a shift in water temperature over a long period may affect Margaritiferidae as greatly as human-induced disturbances.

Two margaritiferid species, Margaritifera laevis and 
Margaritifera togakushiensis are distributed widely in rivers of Hokkaido, Japan (Kondo and Kobayashi, 2005). Margaritifera laevis was confirmed in the Chitose River (Kondo and Kobayashi, 2005). In our preliminary survey, we did not find S. leucomaenis in the Abira River. Furthermore, infection by glochidial larvae of mussels is only observed for O. masou masou (Akiyama, unpublished data). By observation of shell morphology, mussels in the Abira River were identified as $M$. laevis (Kondo, personal communication). These facts indicate that only $M$. laevis is distributed in the Chitose and Abira Rivers. Adult and juvenile mussels are found in the Chitose River, whereas in the Abira River, only adult mussels are found (Akiyama unpublished data). For purposes of conservation, a comparative study is needed to clarify the reason for the absence of juvenile mussels in the latter river. River water was slightly alkalinity in both rivers $(\mathrm{pH}=8.27 \pm 0.43$ in the Abira River and $8.19 \pm 0.16$ in the Chitose River, mean \pm SD) and slightly polluted in the Chitose River, according to the high conductivity $(11.26 \pm 0.36)$ compared to that in the Abira River $\left(4.26 \pm 0.22 \mathrm{mS} \mathrm{m}^{-1}\right)$.

In the present study, survival times of free-living glochidia of $M$. laevis were compared in the laboratory between the population in the Chitose River and that in the Abira River at three levels of water temperature.

\section{MATERIALS AND METHODS}

Gravid mussels were collected from the Abira and Chitose Rivers, central Hokkaido, Japan, on 5 August 2005 during their breeding period. In the field, the valves of each individual were opened slightly with a shell opener, and the soft parts of the mussels were checked by eye for the condition of the marsupium. Mussels with brown and relatively swollen marsupia were judged as having glochidia. Ten incubating mussels were caught randomly from each river and brought to the laboratory. Glochidial release in both rivers begins in late July and ends in early August (Awakura, 1964; Akiyama unpublished data). Water temperatures in both rivers during this period were recorded at hourly intervals with temperature loggers (HOBO Temp Pro, Onset Co.). Mussels from the Chitose and Abira populations were reared separately in two $1 \mathrm{~L}$ containers filled with $900 \mathrm{ml}$ of water from the respective rivers that had been filtrated through glass-fiber filters with a pore size of ca. $0.7 \mu \mathrm{m}$ (Whatman GF/F). The containers were gently aerated with airstones and an air pump to induce the release of glochidia from gravid mussels (Wellmann, 1943). Mussels were returned to respective river habitats after the completion of glochidial release in the laboratory.

The water in the containers was mixed well to achieve a homogenous distribution of glochidia; mean densities of glochidia from the Abira and Chitose Rivers in the containers were 4,015 and 838 individuals $/ \mathrm{ml}$, respectively. From each container containing $900 \mathrm{ml}, 300 \mathrm{ml}$ aliquots were poured into $525 \mathrm{ml}$ containers. Three containers each for the Abira and Chitose Rivers were respectively kept in incubators at 10,15 and $20^{\circ} \mathrm{C}$ under constant aeration. The survival of glochidia was observed nearly daily from $1 \mathrm{ml}$ of water sampled with a measuring pipette from each container. The water was dropped on a counting glass chamber, and live and dead individuals were counted under a binocular microscope one to three times for up to an $0.2 \mathrm{ml}$ sample. Larval death and survival were judged by the presence or absence of damage in cells.

In the present experiment, the survival rate at each temperature was expressed as the ratio of the mean number of live glochidia at each observation time $\left(L_{t}\right)$ to the mean number of live glochidia in triplicate containers at the start of the rearing experiment $\left(L_{0}\right)$. The number of dead glochidia at each observation time $\left(D_{t}\right)$ was obtained by $D_{t}=L_{0}-L_{t}$. The mean numbers of live and dead glochidia observed daily were compared by Pearson's $\chi^{2}$ test between the two populations at the same temperature, and within each population between rearing-water temperatures. In the former case, the Yates correction for continuity (Zar, 1999) was applied to the calculation of $\chi^{2}$. Statistical analyses were performed using the software R-2.4.1 (R Development Core Team, 2006). A p-value less than 0.05 was considered to be statistically significant.

\section{RESULTS}

Glochidia of both the Abira and Chitose River populations survived for 1 day at $15^{\circ} \mathrm{C}$ and $20^{\circ} \mathrm{C}$, but they survived much longer at $10^{\circ} \mathrm{C}, 11$ days in the Abira population and 4 days in the Chitose population (Fig. 1). Survival time of glochidia was thus longest at the lowest temperature, $10^{\circ} \mathrm{C}$. Daily survival rates differed with water temperature within both the Abira population $\left(0-24 \mathrm{~h}, \chi^{2}=1615.2, \mathrm{df}=2, p<0.01\right.$; 24-48h, $\left.\chi^{2}=9071.4, \mathrm{df}=2, p<0.01\right)$ and the Chitose population $\left(0-24 \mathrm{~h}, \chi^{2}=55.2, \mathrm{df}=2, p<0.01 ; 24-48 \mathrm{~h}, \chi^{2}=728.8, \mathrm{df}=2\right.$, $p<0.01)$, but were not always higher at lower temperatures.

Mean water temperature during the breeding period was

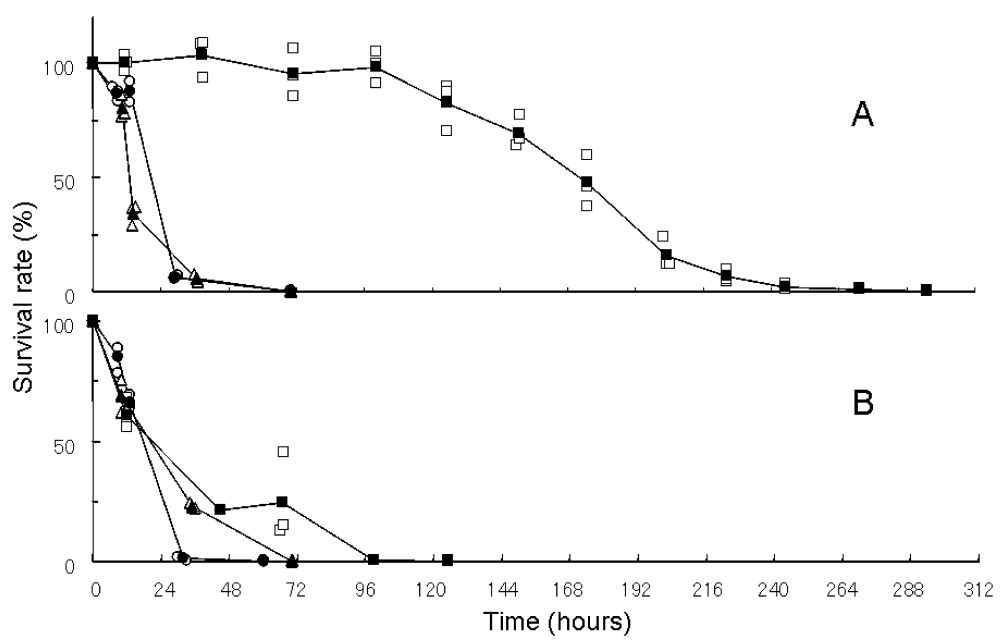

Fig. 1. Survival rates of glochidia of Margaritifera laevis from (A) the Abira River and (B) the Chitose River at three levels of water temperature $\left(\square, 10^{\circ} \mathrm{C} ; \triangle, 15^{\circ} \mathrm{C} ; \bigcirc, 20^{\circ} \mathrm{C}\right)$. Mean survival rate on each observation day is indicated by a filled mark $\left(\boldsymbol{\square}, 10^{\circ} \mathrm{C} ; \boldsymbol{\Delta}, 15^{\circ} \mathrm{C} ; \boldsymbol{O}, 20^{\circ} \mathrm{C}\right)$. 


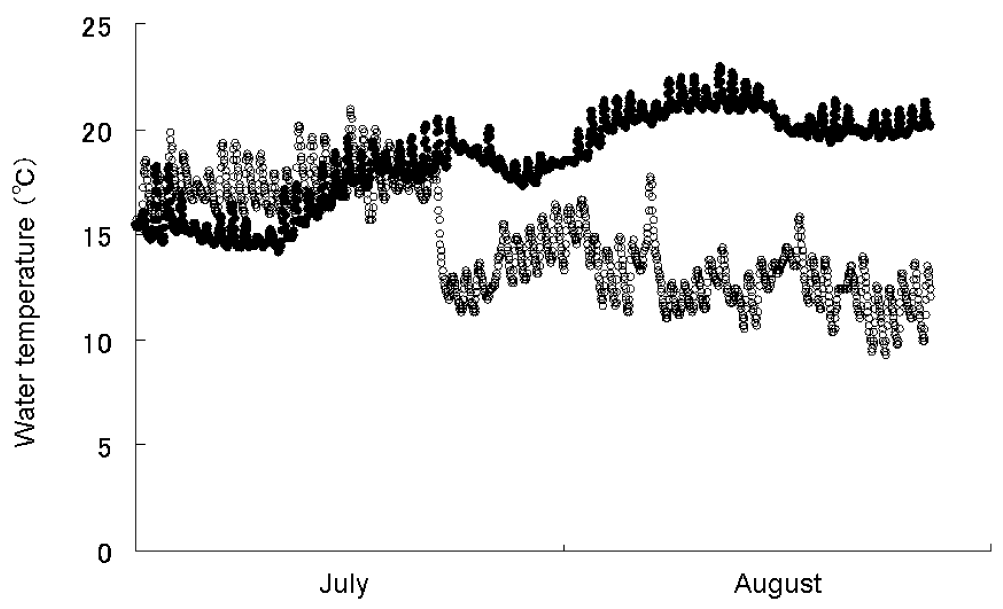

Fig. 2. Hourly bottom water temperature in the Abira River $(\bigcirc)$ and the Chitose River $(\mathbf{O})$ during July and August 2005.

$14.5 \pm 2.0^{\circ} \mathrm{C}($ mean $\pm S D)$ in the Abira River and $19.0 \pm 1.1^{\circ} \mathrm{C}$ in the Chitose River (Fig. 2). Based on these mean water temperatures, mean glochidial survival rates were compared between the Abira River at $15^{\circ} \mathrm{C}$ and the Chitose River at $20^{\circ} \mathrm{C}$. Daily mean survival rates on the first day were significantly lower in the Abira population, but on the second day were significantly higher in the Abira population than in the Chitose population $\left(0-24 \mathrm{~h}, \chi^{2}=140.1, \mathrm{df}=1, p<0.01\right.$; 24-48h, $\left.\chi^{2}=31.9, \mathrm{df}=1, p<0.01\right)$. Mean glochidial survival rate for the Abira population at $15^{\circ} \mathrm{C}$ was $80.4 \% 10 \mathrm{~h}$ after the initiation of the experiment, whereas that for the Chitose population at $20^{\circ} \mathrm{C}$ was $85.3 \% 9 \mathrm{~h}$ after the initiation of the experiment (Fig. 1). During the $4 \mathrm{~h}$ following these times, the mean glochidial survival rate in the Chitose population changed to $66.2 \%$, whereas that in the Abira population dropped sharply to $34.2 \%$ (Fig. 1).

\section{DISCUSSION}

In the present study, an increase in water temperature induced a decrease in the survival time of $M$. laevis glochidia. The density of Oncorhynchus masou masou, a host fish species for $M$. laevis, is also expected to decrease with increasing maximum summer water temperature (Inoue et al. 1997; Inoue and Nakano 2001). This suggests that an increase in water temperature may reduce the chance for glochidial infection of the host, which in turn causes a decrease in the density of the mussel population. Higher water temperatures are observed in narrow lowland rivers lacking vegetation cover above the water surface (Inoue et al. 1997). The life span of mussels in such warm habitats tends to be short (Bauer, 1992), and maintenance of their population may become difficult. Extinction of freshwater pearl mussel populations has been reported mainly for southern Japan (Matsuoka, 1979; Naito, 1989). Groundwater temperature is also higher in low-latitude and lowaltitude areas (Nakano et al., 1996). Extinction of mussel populations and restriction of the mussel distribution to high altitudes in southern Japan might be related to water tem-

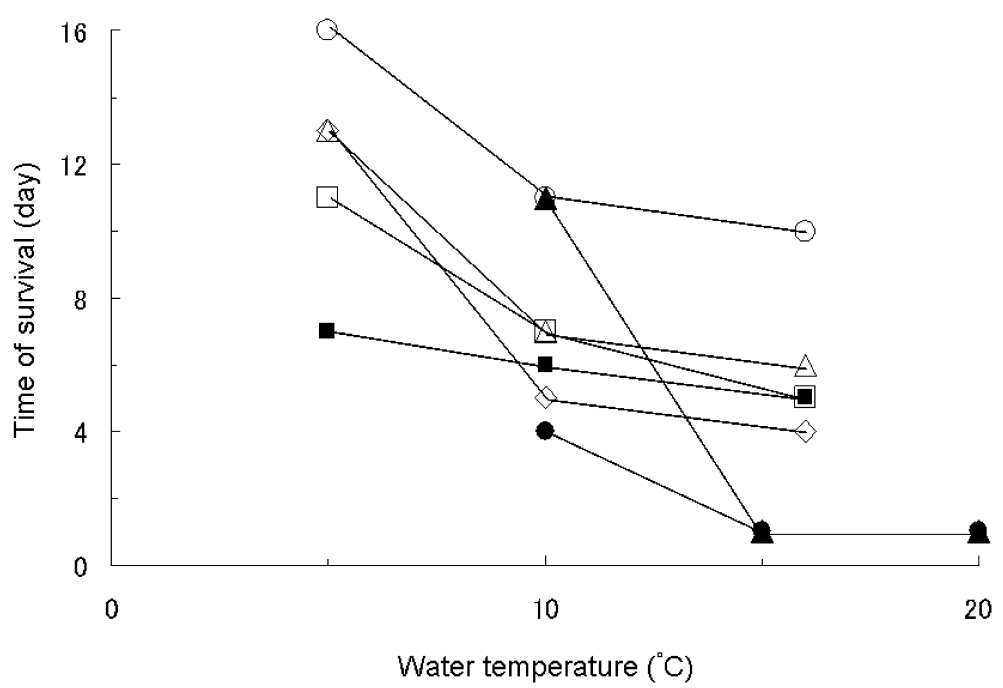

Fig. 3. Comparison of viabilities of glochidia among species of Unionoida at various water temperatures. Margaritifera laevis in the Abira River ( $\mathbf{\Delta})$; Margaritifera laevis in the Chitose River (O); Margaritifera margaritifera ( $\mathbf{\square})$; Unio crassus $(\diamond)$; Unio pictorum $(\bigcirc)$; Anodonta cygnea $(\square)$; Anodonta anatina $(\triangle)$. Data for species except Margaritifera laevis are from Jansen (2001). 
perature.

From 24-48 $\mathrm{h}$ after initiation of the experiment, the survival rate was higher in the Abira population than in the Chitose population, but the survival rate in both populations was very low, i.e., $5.5 \%$ in the Abira population and $0.9 \%$ in the Chitose population. This suggests that the one of key factors in population dynamics might be glochidial viability between $0 \mathrm{~h}$ and $24 \mathrm{~h}$ after release from females. Therefore, one possible cause of lack of juveniles in the Abira population might be a sudden decrease in live glochidial larvae, or high larval mortality as was observed between $9 \mathrm{~h}$ and $14 \mathrm{~h}$ after initiation of the experiment. Not only water temperature but also other factors such as water quality may affect the glochidial surivival rate. For example, glochidial viability of the unionoids Anodonta anatina and $A$. cygnea is reduced by metals such as $\mathrm{Cu}, \mathrm{Cd}, \mathrm{Zn}$, and $\mathrm{Al}$, and by low $\mathrm{pH}$ (Huebner and Pynnonen, 1992).

Glochidial viability of Unionoida, i.e., Unio pictorum, $U$. crassus, Anodonta anatina, A. cygnea and M. margaritifera, decreases with increasing water temperature (Jansen et al., 2001). Viability of Margaritiferidae, including $M$. laevis, at various temperatures tends to be shorter among the Unionoida, except in the case of glochidia in the Abira population at $10^{\circ} \mathrm{C}$ (Fig. 3). This implies that populations of Margaritiferidae cannot be maintained without host fishes around gravid mussels during the period of glochidial release. However, margaritiferid glochidial release does not always coincide with an abundance of host fishes near gravid mussels, because the timing of glochidial release depends on a sudden change in water temperature $\left(>2^{\circ} \mathrm{C}\right)$ and water level $(>0.1 \mathrm{~m})$ (Hastie and Young, 2003). Therefore, the number of juvenile mussels recruited may vary greatly according to glochidial survival, which depends on host behavior during the short period of glochidial release but may be stabilized by abundantly released small glochidia. This trade-off between glochidial size and fertility is beneficial for the mussel at low host density (Bauer, 1994).

\section{ACKNOWLEDGMENTS}

We thank the mayor of Chitose City for permitting the capture of mussels from the Chitose River, without which we could not perform this study. We also thank Prof. T. Kondo, Osaka Kyoiku University, for identification of mussels from the Abira River. This study was supported by Grants-in-Aid for the 21st Century COE Program and for Scientific Research, both from the Ministry of Education, Culture, Sport, Science and Technology through the Japan Society for the Promotion of Science.

\section{REFERENCES}

Awakura T (1964) On the parasitic glochidium of the fresh-water pearl mussel, Margaritifera margaritifera (L.) on salmonid fish. Sci Rep Hokkaido Fish Hatch 19: 1-16 (in Japanese with English Abstract)

Awakura T (1969) On the correlation between the age composition of the freshwater pearl mussel, Margaritifera laevis (Haas) and the population size of salmonid fishes. Sci Rep Hokkaido Fish Hatch 24: 55-87 (in Japanese with English Abstract)

Bauer $G$ (1992) Variation in the life span and size of the freshwater pearl mussel. J Anim Ecol 61: 425-436

Bauer $G$ (1994) The adaptive value of offspring size among freshwater mussels (Bivalvia; Unionoidea). J Anim Ecol 63: 933-944
Bauer G (2001) Factors affecting naiad occurrence and abundance. In "Ecology and Evolution of the Freshwater Mussels Unionoida" Ed by G Bauer, K Wachtler, Springer-Verlag, Berlin, pp $156-162$

Habe T (1982) Freshwater pearl mussel, Margaritifera laevis (Haas) as a gracial relic species. Nihon no Seibutsu 2: 57-63 (in Japanese)

Hastie LC, Young MR (2003) Timing of spawning and glochidial release in Scottish freshwater pearl mussel (Margaritifera margaritifera) populations. Freshwater Biol 48: 2107-2117

Huebner JD, Pynnonen KS (1992) Viability of glochidia of two species of Anodonta exposed to low $\mathrm{pH}$ and selected metals. Canadian J Zool 70: 2348-2355

Inoue M, Nakano S (2001) Fish abundance and habitat relationships in forest and grassland streams, northern Hokkaido, Japan. Ecol Res 16: 233-247

Inoue M, Nakano S, Nakamura F (1997) Juvenile masu salmon (Oncorhynchus masou) abundance and stream habitat relationships in northern Japan. Can J Fish Aquat Sci 54: 1331-1341

Jansen W, Bauer G, Zahner-Meike E (2001) Glochidial mortality in freshwater mussels. In "Ecology and Evolution of the Freshwater Mussels Unionoida" Ed by G Bauer, K Wachtler, SpringerVerlag, Berlin, pp 185-211

Kobayashi O, Kondo T (2005) Difference in host preference between two populations of the freshwater pearl mussl Margaritifera laevis (Bivalvia: Margaritiferidae) in the Shinano river system, Japan. Venus 64: 63-70

Kondo T (1995) Is Margaritifera laevis a glacial relic? Chiribotan 25: 59-63 (in Japanese)

Kondo T (2005) Margaritifera laevis (Haas, 1910). In "Threatened Wildlife of Japan, Red Data Book Vol 6 Land and Freshwater Mollusks" 2nd ed Ed by Ministry of the Environment, p 301 (in Japanese)

Kondo T, Kobayashi O (2005) Revision of the genus Margaritifera (Bivalvia: Margaritiferidae) of Japan, with description of a new species. Venus 64: 135-140

Matsuoka K (1979) Conservation of freshwater pearl mussel, Margaritifera laevis. Freshwater Fish 5: 122-125 (in Japanese)

Naito J (1989) Conservation of freshwater pearl mussel, Margaritifera laevis in the Geihoku city, Hiroshima prefecture. Freshwater Fish Conserv 89: 99-101 (in Japanese)

Nakano S, Kitano F, Maekawa K (1996) Potential fragmentation and loss of thermal habitats for charrs in the Japanese archipelago due to climatic warming. Freshwater Biol 36: 711-722

R Development Core Team (2006) R: A language and environment for statistical computing. R Foundation for Statistical Computing, Vienna, Austria. http://www.R-project.org

Yoshida Y (1971) Distribution of freshwater pearl mussel and conservation. Anim Nat 1: 2-6 (in Japanese)

Yoshida Y (1973) Distribution of freshwater pearl mussel and Action for mussel conservation. Biol Edu Gifu Pref 18: 19-26 (in Japanese)

Wachtler K, Dreher-Mansur CM, Richter T (2001) Larval types and early postlarval biology in naiads (Unionoida). In "Ecology and Evolution of the Freshwater Mussels Unionoida" Ed by $G$ Bauer, K Wachtler, Springer-Verlag, Berlin, pp 93-125

Watters GT, Scott HO (1998) Metamorphosis of freshwater mussel glochidia (Bivalvia: Unionidae) on amphibians and exotic fishes. Am Midl Nat 139: 49-57

Wellmann G (1943) Fischinfektionen mit glochidien der Margaritifera margaritifera. Z Fischerei 41: 385-390

Zar JH (1999) Biostatistical Analysis. 4th ed, Prentice Hall, Upper Saddle River, NJ

(Received February 7, 2007 / Accepted May 16, 2007) 